\title{
Interventional analgesic block in a dog with cauda equina syndrome. Case report
}

\author{
Bloqueio analgésico intervencionista em cão com síndrome da cauda equina. Relato de caso
}

Rodrigo Mencalha1, Camila de Souza Generoso' ${ }^{1}$, Daniel Sacchi de Souza ${ }^{1}$

DOI 10.5935/2595-0118.20190034

\section{ABSTRACT}

BACKGROUND AND OBJECTIVES: The cauda equina syndrome is a neurological condition prevalent in dogs which neurological signs are caused by the compression of the nerve roots located in the lumbosacral spinal canal and is frequently associated with pain, claudication, paresis or paralysis of the hindlimbs and changes in the functioning of the sphincters. The objective of this study was to check the effects of the epidural injection with the combination of dexamethasone, bupivacaine and morphine on the relief of pain and neurological signs in a dog with traumatic cauda equina syndrome.

CASE REPORT: Case study of a 2-year old Red Heeler dog, weighing $16 \mathrm{~kg}$ with a diagnosis of post-trauma cauda equina syndrome. The evaluation consisted of neurological and pain assessment (visual analog scale), quality of life (" $5 \mathrm{H} 2 \mathrm{M}$ ") and infrared thermography. After the initial evaluation and authorization of the tutor, the dog was submitted to general anesthesia and a lumbosacral epidural block, guided by electrostimulation, with the association of dexamethasone, bupivacaine and morphine. After the procedure, the dog showed immediate remission of claudication, paresis and satisfactory analgesia on days 0,15 , 30 and 60 after the intervention.

CONCLUSION: The epidural block was effective in improving pain, quality of life and neurological signs and may be an excellent alternative in dogs with pain syndromes associated with the spinal canal.

Keywords: Epidural anesthesia, Cauda equina syndrome, Pain, Polyradiculopathy, Veterinary.

Rodrigo Mencalha - (1)https://orcid.org/0000-0002-5941-2902;

Camila de Souza Generoso - (Dhttps://orcid.org/0000-0003-4885-7487;

Daniel Sacchi de Souza - (Dhttps://orcid.org/0000-0002-5401-8447.

1. Faculdade de Medicina Veterinária, Centro de Ensino Superior de Valença, Valença, RJ, Brasil.

Submitted on November 20, 2018.

Accepted for publication on February 18, 2019.

Conflict of interests: none - Sponsoring sources: none.

Correspondence to:

Rua Sargento Vitor Hugo, 161 - Fátima

27600-000 Valença, RJ, Brasil.

E-mail: rodrigo.mencalha@faa.edu.br

(C) Sociedade Brasileira para o Estudo da Dor

\section{RESUMO}

JUSTIFICATIVA E OBJETIVOS: A síndrome da cauda equina é uma afecção neurológica prevalente em cáes cujos sinais neurológicos sáo causados pela compressão de raízes nervosas localizadas no canal espinhal lombossacral sendo frequentemente associada à dor, claudicação, paresia ou paralisia de membros pélvicos e alterações do funcionamento dos esfíncteres. $\mathrm{O}$ objetivo deste estudo foi verificar os efeitos da injeção peridural com a associaçáo de dexametasona, bupivacaína e morfina no alívio da dor e dos sinais neurológicos em um cáo com síndrome da cauda equina de origem traumática.

RELATO DO CASO: Estudo do caso de um animal da espécie canis familiaris, raça red heeler, fêmea, 2 anos de idade e $16 \mathrm{~kg}$ de peso corporal com diagnóstico de síndrome da cauda equina pós-trauma. A avaliaçáo consistiu no exame neurológico completo, avaliação de dor (escala analógica visual), de qualidade de vida ("5H2M") e por termografia infravermelha. Após a avaliação inicial e autorizaçáo do tutor, a cadela foi submetida à anestesia geral e a um bloqueio intervencionista peridural lombossacral, guiado por eletroestimulação, com a associação de dexametasona, bupivacaína e morfina. Após o procedimento, a cadela apresentou imediata remissão da claudicação, da paresia e uma satisfatória analgesia nos dias 0, 15, 30 e 60 após a intervenção. CONCLUSÃO: O bloqueio peridural intervencionista foi eficaz na melhora da dor, da qualidade de vida e dos sinais neurológicos, podendo ser uma excelente alternativa em cáes com síndromes dolorosas associadas ao canal espinhal.

Descritores: Anestesia peridural, Cauda equina, Dor, Polirradiculopatia, Veterinária.

\section{INTRODUCTION}

Cauda equina syndrome (CES) is a neurological condition prevalent in dogs whose signs appear due to the compression of the nerve roots called cauda equina. Anatomically, these roots, located between the $7^{\text {th }}$ lumbar vertebrae and the $5^{\text {th }}$ coccygeal vertebrae, may be the target of multifactorial compressions ${ }^{1}$.

The clinical signs most observed in these animals are associated with pain in the lumbosacral region, limb claudication of the pelvic limbs, with or without muscle weakness ${ }^{2}$, and may present paresis or paralysis. Also, the presence of changes in proprioception and urinary and/or fecal incontinence is not uncommon ${ }^{3}$. The syndrome usually happens with changes in the animal's daily activities such as running, jumping, climbing stairs, and exercise usually exacerbates these signs ${ }^{3}$. 
Conventional diagnosis usually associates the animal's history with clinical and neurological findings. However, imaging scans such as radiography and computerized tomography are essential for determining the exact location of the injury. In addition, infrared thermography may contribute to the determination of peripheral and central neuropathic syndromes in humans ${ }^{4-7}$, so that, it is possible that it has good predictive value in the diagnosis of CES in dogs. Among the clinical findings, the presence of proprioceptive deficits, muscular atrophy, paraparesis, and urinary and fecal incontinence are notorious ${ }^{8}$.

In veterinary medicine, the conservative treatment with the use of anti-inflammatories is one of greater adhesion among the professionals. However, depending on the severity of the injuries, decompression surgery may be critical to the positive outcome. The prognosis depends on the etiology, time elapsed of the disease, the degree of neurological impairment and the type of treatment used?

The objective of this study was to verify the effects of epidural injection with the association of dexamethasone, bupivacaine, and morphine on pain relief, on quality of life improvement and neurological signs in a dog with traumatic CES.

\section{CASE REPORT}

This is a case report study, which the Free and Informed Consent Form (FICT) of the Valença Higher Education Center of the Dom André Arcoverde Educational Foundation has been explained and signed by the person responsible for the animal, who was aware of all the stages of the study. Interventionist analgesic blockade was performed in the operating room on the day scheduled with the guardian of the animal after signing the FICT.

On evaluation day, the evaluator A performed basic neurological examinations such as superficial and deep pain tests, panniculus reflex, patellar tendon reflexes, and proprioception. Evaluator A observed severe limb claudication in the left pelvic limb, bilateral patellar hyperreflexia and conscious proprioception deficit in the left pelvic limb. There was no change in urinary and anal sphincter function.

The evaluator B evaluated pain and quality of life (QoL) using the visual analog scales (VAS) and QoL " $5 \mathrm{H} 2 \mathrm{M}$ ", respectively, and a complete infrared thermography examination. The VAS is a numerical scale from zero (absence of pain) to 10 (worst pain imaginable), in which the tutor was asked to indicate, quantitatively, the pain presented at the time of evaluation. The QoL scale is an instrument developed to assist tutors and veterinarians in bioethical decisions related to life and death. This scale is known as " $5 \mathrm{H} 2 \mathrm{M}$ " which evaluates the clinical status of the animal through the parameters $\mathrm{H}$-hurt, $\mathrm{H}$-hunger, H-hydration, H-hygiene, H-happiness), M-mobility and M-more good than bad days. The $5 \mathrm{H} 2 \mathrm{M}$ is a numerical scale from zero to 70 with the score of 35 being the minimum acceptable to attest adequate QoL ${ }^{10}$. Infrared thermography was performed with a FLIR T420 camera in an air-controlled environment at $21^{\circ} \mathrm{C}, 60 \%$ relative humidity, with no light and respecting the acclimation period of 20 minutes as recommended by the American Infrared Thermography Guidelines for Animals ${ }^{11}$.
The pain score defined by the tutor's evaluation was VAS $=8$, and the QoL score was " $5 \mathrm{H} 2 \mathrm{M}$ " $=20$. In the thermographic examination, there were significant changes in the thermal patterns in the dermatomeres (secondary hypo radiation to the sympathetic neurovegetative hyperreactivity) of the left pelvic limb (affected) in different segments, namely: EI1 and EI2 = knee medial facet; EI3 and EI4 dorsal aspect of the tibiotarsal joint; EI5 and EI6 dorsal aspect of the metatarsus (Figure 1).

After initial evaluations and data collection, the animal was referred to the operating room for an interventionist analgesic blockade. The technique chosen in this study was based on the data observed in humans ${ }^{12}$ and also on the difficulty of the tutor in adhering to the conservative treatment with oral anti-inflammatory because it is a herding dog whose dwelling in a rural area would interfere with the administration of the drug.

Thus, electro stimulation-guided epidural administration combining dexamethasone $(4 \mathrm{mg})^{13}$, bupivacaine $0.125 \%(0.22 \mathrm{~mL}$. $\left.\mathrm{kg}^{-1}\right)$, and morphine $\left(0.1 \mathrm{mg} \cdot \mathrm{kg}^{-1}\right)^{14}$ was the selected approach.

Based on the above, the technique proposed in the study followed the order below:

Intravenous catheterization with a $22 \mathrm{G}$ device and anesthetic induction with $4 \mathrm{mg} \cdot \mathrm{kg}^{-1}$ of propofol. The animal was kept in $100 \%$ oxygen under an orofacial mask; electrocardiographic monitoring in DII, pulse oximeter, plethysmography, and noninvasive blood pressure; rigorous trichotomy and antisepsis of the lumbosacral region. A 50mm gage neurostimulation needle was introduced in the lumbosacral region (L7-S1) with the neuro localizer calibrated at $0.7 \mathrm{~mA}, 0.1 \mathrm{~ms}$ and $1 \mathrm{~Hz}^{15}$; localization of the epidural space after motor responses of abduction of the pelvic limbs and tail lateralization; infiltration of the dexamethasone, bupivacaine and morphine solution with slow injection for about 60 seconds.

After the analgesic blockade, the animal was taken to the post-anesthetic recovery room and discharged after 60 minutes of observation. Besides, the need for a veterinary reassessment was clarified to the tutor on 15, 30 and 60 days after the intervention, since in case of no remission of symptoms, further epidural infiltration may be necessary.

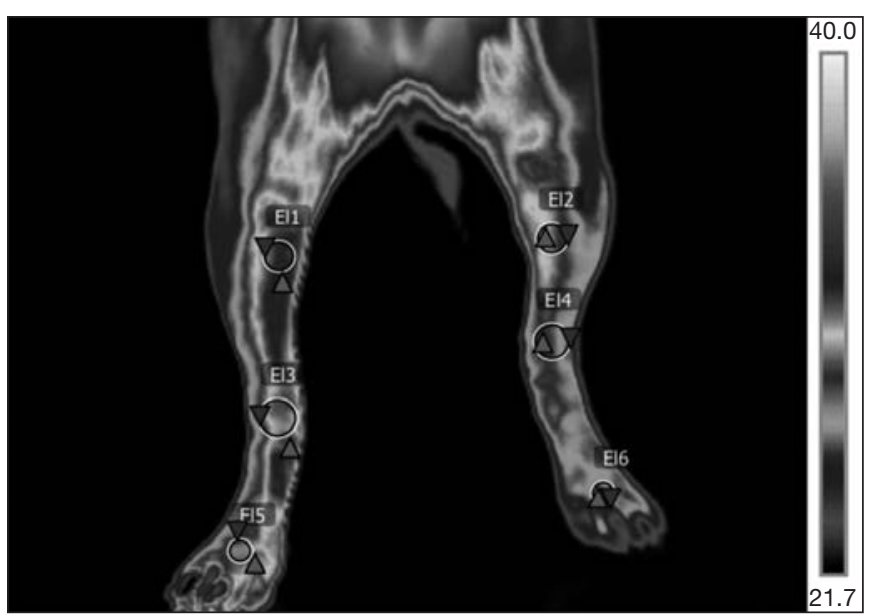

Figure 1. Thermography of the dog's pelvic limbs in the position of two supports

El1 (mean 31.9 $\mathrm{C}$ ); El2 (mean $29.5^{\circ} \mathrm{C}$ ); El3 (mean $30.7^{\circ} \mathrm{C}$ ); El4 (mean $28.0^{\circ} \mathrm{C}$ ); EI5 (mean $29.8^{\circ} \mathrm{C}$ ); EI6 (mean $27.3^{\circ} \mathrm{C}$ ). Temperature variation $(\mathrm{El}-1-\mathrm{EI} 2)=2.4^{\circ}$ $\left.\mathrm{C} ;(\mathrm{EI} 3-\mathrm{E} \mid 4)=2.7^{\circ} \mathrm{C} ;(\mathrm{EI} 5-\mathrm{E} \mid 6)=2.5^{\circ} \mathrm{C}\right)$. 
Table 1. Neurological signs, pain score, and quality of life pre- and post-intervention

\begin{tabular}{lcccc}
\hline Domains & Pre-intervention (Day 0) & Post-intervention (Day 15) & Post-intervention (Day 30) & Post-intervention (Day 60) \\
\hline Claudication & Present in LPL & Discrete in LPL & Absent & Absent \\
Pain (VAS) & 8 & 2 & 0 & 0 \\
Reflex of the Panniculus & Normal & Normal & Normal & Normal \\
Proprioception & Decreased in LPL & Normal & Normal & 70 \\
Quality of Life ("5H2M") & 20 & 50 & Normal & Normal \\
Patellar Reflex & Increased in RPL/LPL & Increased in RPL/LPL & & 70 \\
\hline VAS = visual analog scale; LPL = left pelvic limb; RPL = right pelvic limb
\end{tabular}

The clinical signs, pain scores, and QoL were reassessed 15, 30 and 60 days after the procedure and the skin temperature and thermographic image were repeated 60 days later. The data collected in the pre- and post-intervention phases were registered in the Windows Microsoft Excel, Software version 2016.

Table 1 presents the pain data, measured by VAS and QoL evaluated by the " $5 \mathrm{H} 2 \mathrm{M}$ " pre- and post-analgesic intervention. Through VAS, it was observed that the dog had a decrease in pain intensity after 15 days of the intervention (VAS=2), reaching a zero score as of day 30. In the QoL assessment, the score reached 70 points in the day 60 evaluation.

Table 2 presents data referring to the cutaneous thermometry of the EI1 and EI2 regions (medial face of the knee); EI3 and EI4 (dorsal aspect of the tibiotarsal joint) and EI5 and EI6 dorsal aspect of the metatarsal before and after the intervention. Figure 2 shows the thermal image of the affected and contralateral limbs performed 60 days after the intervention. Infrared thermography monitoring showed a significant improvement in the sympathetic vasomotor hyperreactivity of the left pelvic limb (affected) in segments 2,4 and 6 with a temperature difference of $1.0^{\circ} \mathrm{C}, 0.1^{\circ}$ $\mathrm{C}$ and $0.4^{\circ} \mathrm{C}$, in relation to the contralateral limb, respectively. In general, the animal presented clinical improvement in all domains evaluated, including neurological signs (proprioception, patellar reflex, claudication, and cutaneous panniculus reflex) and pain and QoL scores.

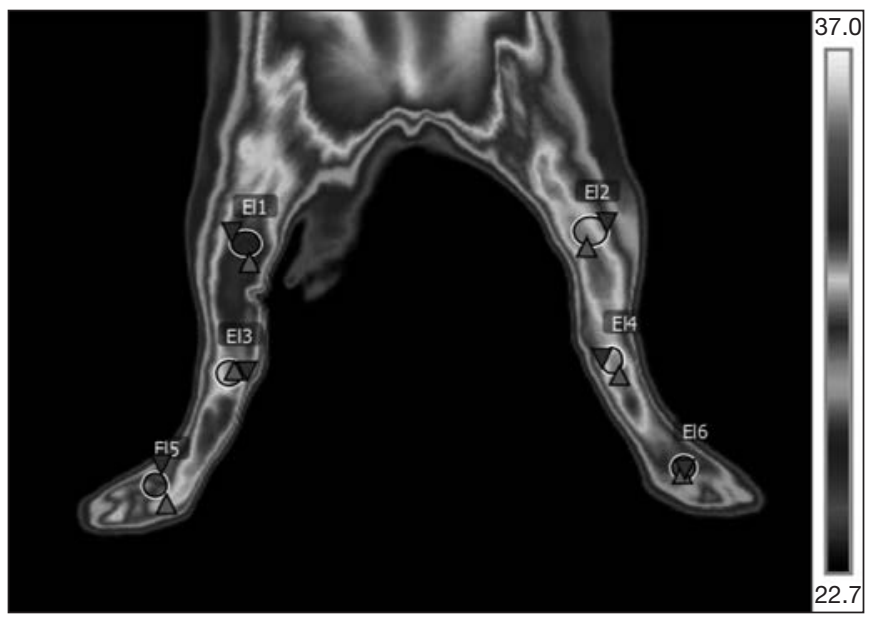

Figure 2. Thermographic image of the pelvic limbs of the dog in position on two supports

El1 (mean $\left.32.0^{\circ} \mathrm{C}\right)$; El2 (mean $\left.31.0^{\circ} \mathrm{C}\right)$; El3 (mean $\left.31.2^{\circ} \mathrm{C}\right)$; El4 (mean $\left.31.1^{\circ} \mathrm{C}\right)$; $\mathrm{EI5}$ (mean 29.8 $\mathrm{C}$ ); EI6 (mean $\left.29.4^{\circ} \mathrm{C}\right)$. Temperature variation $(\mathrm{El}-1-\mathrm{El} 2)=1.0^{\circ}$ $\left.\mathrm{C} ;(\mathrm{EI}-\mathrm{EI} 4)=0.1^{\circ} \mathrm{C} ;(\mathrm{E}|5-\mathrm{E}| 6)=0.4^{\circ} \mathrm{C}\right)$.
Table 2. Cutaneous thermometry of the El1 and El2 regions (medial face of the knee); EI3 and El4 (dorsal aspect of the tibiotarsal joint)

\begin{tabular}{lcc}
\hline Regions & Pre-intervention (Day 0) & Post-intervention (Day 60) \\
\hline El1 & $31.9^{\circ} \mathrm{C}$ & $32.0^{\circ} \mathrm{C}$ \\
El2 & $29.5^{\circ} \mathrm{C}$ & $31.0^{\circ} \mathrm{C}$ \\
El1-EI2 & $2.4^{\circ} \mathrm{C}$ & $1.0^{\circ} \mathrm{C}$ \\
El3 & $30.7^{\circ} \mathrm{C}$ & $31.2^{\circ} \mathrm{C}$ \\
El4 & $28.8^{\circ} \mathrm{C}$ & $31.1^{\circ} \mathrm{C}$ \\
El3-EI4 & $2.7^{\circ} \mathrm{C}$ & $0.1^{\circ} \mathrm{C}$ \\
El5 & $29.8^{\circ} \mathrm{C}$ & $29.8^{\circ} \mathrm{C}$ \\
El6 & $27.3^{\circ} \mathrm{C}$ & $29.4^{\circ} \mathrm{C}$ \\
El5-EI6 & $2.5^{\circ} \mathrm{C}$ & $0.4^{\circ} \mathrm{C}$ \\
\hline
\end{tabular}

\section{DISCUSSION}

CES in dogs is a neurological condition whose clinical signs are related to the nerve root lesion of the $7^{\text {th }}$ lumbar vertebra, sacral or coccygeal vertebrae, caused by dorsoventral stenosis of the vertebral canal ${ }^{1}$. Congenital stenosis, disc protrusions, and spondylosis are among the most frequent disorders of the syndrome. However, traumatic situations such as vertebral fractures and dislocations and diskospondylitis (spondylodiscitis) are also associated with this syndrome

In the present report, it was observed dorsoventral stenosis of the vertebral canal in the lumbosacral region without the involvement of sacral or coccygeal vertebrae. Clinical signs are inherent to the affected segment of the medulla and/or involved nerve, so, depending on the affected region it is common to observe the presence of lumbosacral pain, claudication, muscular atrophy in the area inherent to the sciatic nerve, paresis, tail weakness, urinary and/or fecal incontinence disorders and paresthesia ${ }^{2}$.

Lumbosacral pain is the most prevalent clinical characteristic in these animals. Therefore, the presence of an antalgic posture with hyperkyphosis of the spine is notorious. In the present report, the tutor's search for pain and palliative care was due to the animal's reluctance to perform common activities such as running, playing or jumping. Also, it was reported by the tutor the refusal of food in the days before the appointment. In addition to the notorious presence of lumbosacral pain, the animal in this report presented severe claudication in the left pelvic limb. This clinical sign is the second most frequent in this syndrome, which is associated with pain referred by the incarceration of the nerve roots of L6, L7, and S1. These roots contribute to the formation of the sciatic nerve, and its compromising may lead to motor deficits ${ }^{16}$. 
The motor activity contributes to the increase in the circulatory demand of the spinal cord and cauda equina. However, due to spinal canal stenosis, hypoperfusion results in ischemia of the nerve roots and subsequent root pain and/or referred pain in the limbs, tail, and perineum ${ }^{9}$. The images obtained by infrared thermography corroborate this statement since an intense area of hyporadiation was observed in the left pelvic limb, secondary to sympathetic neurovegetative hyperreactivity, probably due to the incarceration of the nerve roots of L7 and S1.

Paresis or paralysis of the pelvic limbs only occurs when the nerve roots of L4 to S2 are affected or even in the traumatic injuries of the nerves that make up the limb. However, if the sciatic nerve is affected, the animal can support the weight of the resting limb on the back of the paw ${ }^{16}$. In the present report, intermittent paresis of the left pelvic limb was observed, which was totally eliminated after the interventionist blockade.

The urination and defecation reflexes were not altered in this studied animal. Usually, they will be absent when lesions occur in the nerve roots or segments of the spinal cord from $S 1$ to $S 3$ whose sites contribute to the formation of the pudendal nerve. The injuries inherent to the cranial segments in this region do not compromise the functioning of these sphincters ${ }^{17}$. When lesions are associated only with the sacral and coccygeal nerve roots, the presence of atonic tail is also prevalent, which was also not observed in the dog of this study.

Paresthesia occurs as a result of irritation of sensitive fibers of the cauda equina which are derived from dermatomeres innervated by the sciatic and pudendal nerves, due to the compression of the vertebral canal. These abnormal sensations can occur with burning, stinging, tingling or shock, which induces the animal to lick and/or bite the affected areas causing dermatological abrasions and self-mutilation $^{8}$. After the appointment, the tutor reported an excess of bite in the lumbosacral region. However, due to the presence of ectoparasites, it was not possible to attest the reliability of this information. The treatment of animals affected by CES is directed to the cause and severity of the injury, being classified as conservative or surgical. Usually, conservative treatment in veterinary medicine is based on the systemic use of anti-inflammatory/analgesic and confinement. However, due to the long period of treatment, the known adverse effects inherent in non-steroidal anti-inflammatory drugs and corticosteroids are frequent in these animals ${ }^{18}$. Thus, due to recent advances in the area of pain interventionist medicine, this study preconized the use of anti-inflammatory and analgesic drugs directly at the site of the injury to optimize anti-inflammatory and analgesic therapy and minimizing longterm use of these drugs and their subsequent adverse effects.

Interventionist pain medicine is a broad area of medicine that offers many possibilities for diagnosis and treatment of many types of pain, through minimally invasive procedures, usually with the use of needles. Imaging tests such as ultrasound and radiographs are critical to the accuracy of drug infusion into the desired target and to minimize the risks of iatrogenic failures and injuries. In the present report, epidural analgesic blockade (lumbosacral translaminar) with the combination of dexamethasone, bupivacaine, and morphine was chosen. Bupivacaine is a local anesthetic that promotes long-term motor and sensory blockade. However, the use of low-concentration bupivacaine $(0.125 \%)$ was preconized to avoid motor blockage of the pelvic limbs. The association of morphine with the analgesic combination aimed at the installation of long-term analgesia because, due to its low degree of ionization, it is estimated that its analgesia is of nearly 16 hours when administered via epidural ${ }^{19,20}$. The use of epidural dexamethasone is not a common practice in veterinary medicine. However, it has been highly explored in interventionist blockades in humans. Corticosteroids exert their anti-inflammatory action, interrupting the arachidonic acid pathway of the damaged cell membrane. Its epidural use is associated with the reduction of the edema, fibrin deposition, capillary dilatation, leukocyte migration, capillary fibroblast proliferation, and collagen deposition ${ }^{8}$. In addition, some studies suggest that corticosteroids may reduce the hyperexcitability of the nerve cell by directly affecting the cell membrane conduction'. Thus, since CES often presents with edema of the nerve roots and an intense inflammatory process, the choice of interventionist analgesic treatment has substantial support since the mechanism of action of these drugs leads to the reduction of the edema of the nerve roots and even the adjacent tissues.

Among the corticosteroids described for use in epidural injection in humans stand out the methylprednisolone acetate, triamcinolone salts, and dexamethasone ${ }^{9}$. In humans, methylprednisolone is the most widely used drug with doses ranging from 40 to $120 \mathrm{mg}$ per injection. Dexamethasone has been frequently used in analgesic blockades with the main advantage being its high potency and duration. In veterinary medicine, only one study reports the use of epidural dexamethasone ${ }^{13}$. This work evaluated the analgesic influence of different doses of dexamethasone $(2,4$ and $8 \mathrm{mg})$ associated with lidocaine in dogs submitted to ovary salpingohisterectomy. It was observed in this study that there was a growing potentiation of postoperative analgesia with the use of epidural dexamethasone in a dose-dependent manner. The first veterinary clinical study with epidural corticosteroids evaluated 38 dogs with Hansen lumbosacral disc protrusion type II after epidural infiltration of methylprednisolone acetate. In that study, the epidural infiltration, performed by fluoroscopy, was carried at standard intervals for the first three treatments and, subsequently, on demand, which improvement was perceived by the tutor in $79 \%$ of the animals and $53 \%$ were considered totally cured ${ }^{18}$.

An important factor in the administration of corticosteroids via epidural is the choice of the diluent. Usually, the association should be performed with an isotonic physiological solution or local anesthetic. Some authors have been recommending dilution in local anesthetic because it gives the patient better comfort after epidural injection ${ }^{8}$.

The volume of the epidural solution is also the subject of intense discussion in veterinary medicine. Traditionally, it is recommended the use of an average volume of about $0.25 \mathrm{~mL} \cdot \mathrm{kg}^{-1}{ }^{21}$. However, larger volumes are used when more cranial dermatomeres are desired ${ }^{22}$. In humans, the discussion of this subject is also wide and controversial. Some authors believe that small volumes of the solution are insufficient to reach the ventral aspect of the epidural space. However, other authors believe that the effect of the corticosteroid is independent of the volume injected but is due to the closest possible administration to the affected site ${ }^{12}$. 
In case only one corticosteroid epidural injection is enough to relieve pain, and neurological signs of the patient usually are not indicated to repeat the procedure ${ }^{1}$. In the present report, the remission of clinical signs associated with pain and neurological components were solved with a single injection of the proposed combination. In humans, some patients respond well to the second or third epidural corticosteroid injection ${ }^{12}$. However, there are no reports of repeated injections into companion animals.

Because this is an exclusively interventionist analgesic procedure, the failure of the technique becomes more severe than the anesthetic epidural blockade performed by surgery because, in case of perioperative technique failure, another analgesic modality is promptly put in place. Therefore, it is essential that the procedure is performed with equipment that minimizes the risk of erratic injection, such as the peripheral nerve stimulator and/or ultrasound. In the present report, the epidural injection was performed with the aid of the peripheral nerve stimulator regulated at $0.7 \mathrm{~mA}, 0.1 \mathrm{~ms}$, and $1 \mathrm{~Hz}^{15}$. In humans, the use of fluoroscope has gained prominence in the last decade and has been used in almost all interventionist blockades.

The wide clinical epidural use of corticosteroids in humans is generally related to the relief of pain syndromes resulting from inflammation of the neural structures of the epidural and perineural spaces ${ }^{12}$, which may be used for low back pain, sciatic pain, sacral pain, radicular pain, radiculopathy, lumbosciatalgy, nerve root compression, protrusion, prolapse or disc hernia and lumbar canal stenosis. Thus, it is valid the discussion about the epidural use of corticosteroids in these syndromes mentioned in dogs and cats since the result is likely to be similar to those obtained in humans.

The complications inherent to interventionist epidural blockade are associated with the technique itself and the side effects of the selected drugs. The complications of the technique are perforation of the dura-mater, accidental subarachnoid or intravascular injection. The minor complications, when the interventionist blockade is associated with the local anesthetic, are arterial hypotension, motor block, and prolonged sensory block. Major complications include meningitis, systemic infection, epidural hematoma, abscess, CES, neurotoxicity, and the development of hyperadrenocorticism when corticosteroids are used ${ }^{12}$.

\section{CONCLUSION}

Interventionist epidural blockade was effective in pain relief, QoL, and neurological signs, and may be an excellent alternative in dogs with pain syndromes associated with the spinal canal.

\section{REFERENCES}

1. Orendácová J, Marsala M, Sulla I, Kafka J, Jalc P, Cizková D, et al. Incipient cauda equina syndrome as a model of somatovisceral pain in dogs: spinal cord structures involved as revealed by the expression of c-fos and NADPH diaphorase activity. Neuroscience. 2000;95(2):543-57.

2. Tan JM, Wu J, Shi JG, Shi GD, Liu YL, Liu XH, et al. Brain-derived neurotrophic factor is up-regulated in severe acute cauda equina syndrome dog model. Int J Clin Exp Med. 2013;6(6):431-7.

3. Saey V, Martlé V, Van Ham L, Chiers K. Neuritis of the cauda equina in a dog. J Small Anim Pract. 2010;51(10):549-52.

4. Neves EB, Vilaça-Alves J, Rosa C, Reis VM. Thermography in neurologic practice Open Neurol J. 2015;9:24-7.

5. Niehof SP, Huygen FJ, van der Weerd RW, Westra M, Zijlstra FJ. Thermography imaging during static and controlled thermoregulation in complex regional pain syndrome type 1: diagnostic value and involvement of the central sympathetic system. Biomed Eng Online. 2006;5:30.

6. Niehof SP, Beerthuizen A, Huygen FJ, Zijlstra FJ. Using skin surface temperature to differentiate between complex regional pain syndrome type 1 patients after a fracture and control patients with various complaints after a fracture. Anesth Analg. 2008;106(1):270-7.

7. Gulevich SJ, Conwell TD, Lane J, Lockwood B, Schwettmann RS, Rosenberg N, et al. Stress infrared telethermography is useful in the diagnosis of complex regional pain syndrome, type I (formerly reflex sympathetic dystrophy). Clin J Pain. 1997;13(1):50-9.

8. De Decker S, Watts V, Neilson DM. Dynamic lumbosacral magnetic resonance imaging in a dog with tethered cord syndrome with a tight filum terminale. Front Vet Sci. 2017;4:134.

9. Spector LR, Madigan L, Rhyne A, Darden B 2nd, Kim D. Cauda equina syndrome. J Am Acad Orthop Surg. 2008;16(8):471-9.

10. Villalobos AE. Quality-of-life assessment techniques for veterinarians. Vet Clin North Am Small Anim Pract. 2011;41(3):519-29.

11. Turner TA, Waldsmith J, Marcella K, Henneman K, Purohit RC, Morino D, et al Veterinary guidelines for infrared thermography. The American Academy of Thermology. https://aathermology.org/organization-2/guidelines/veterinary-guidelines-for-infrared-thermography/.

12. Cocicov AF, Cocicov HL, da Silva MB, Skare TL. [Epidural steroids for low back pain syndromes]. Rev Bras Anestesiol. 2004;54(1):129-41. English, Portuguese.

13. Hermeto LC, Rossi R, Bicudo NA, Assis KT, Escobar LL, Camargo PS. The effect of epidurally administered dexamethasone with lignocaine for post-operative analgesia in dogs undergoing ovariohysterectomy. A dose-response study. Acta Cir Bras. 2017;32(4):307-18.

14. Steagall PVM, Simon BT, Teixeira Neto FJ, Luna SPL. An update on drugs used for lumbosacral epidural anesthesia and analgesia in dogs. Front Vet Sci. 2017;4:68.

15. Otero PE, Verdier N, Ceballos MR, Tarragona L, Flores M, Portela DA. The use of electrical stimulation to guide epidural and intrathecal needle advancement at the L5L6 intervertebral space in dogs. Vet Anaesth Analg. 2014;41(5):543-7.

16. Marsala J, Sulla I, Jalc P, Orendacova J. Multiple protracted cauda equina constrictions cause deep derangement in the lumbosacral spinal cord circuitry in the dog. Neurosci Lett. 1995;193(2):97-100.

17. Kaiser R, Nasto LA, Venkatesan M, Waldauf P, Perez B, Stokes OM, et al. Time factor and disc herniation size: are they really predictive for outcome of urinary dysfunction in patients with cauda equina syndrome? Neurosurgery. 2018;83(6):1193-200.

18. Janssens L, Beosier Y, Daems R. Lumbosacral degenerative stenosis in the dog. The results of epidural infiltration with methylprednisolone acetate: a retrospective study. Vet Comp Orthop Traumatol. 2009;22(6):486-91.

19. Rosen MA, Hughes SC, Shnider SM, Abboud TK, Norton M, Dailey PA, et al. Epidural morphine for the relief of postoperative pain after cesarean delivery. Anesth Analg. 1983;62(7):666-72.

20. Fuller JG, McMorland GH, Douglas MJ, Palmer L. Epidural morphine for analgesia after caesarean section: a report of 4880 patients. Can J Anaesth. 1990;37(6):636-40.

21. Dias RSG, Soares JHN, Castro DDSE, Gress MAKA, Machado ML, Otero PE, et al. Cardiovascular and respiratory effects of lumbosacral epidural bupivacaine in isoflurane-anesthetized dogs: the effects of two volumes of $0.25 \%$ solution. PLoS One. 2018;13(4):e0195867.

22. Valverde A. Epidural analgesia and anesthesia in dogs and cats. Vet Clin North Am Small Anim Pract. 2008;38(6):1205-30. 